\title{
An Update of the Vox Populi Approach to Academic Journal Rankings: 2011 in Review
}

\author{
James E. Richard \\ Victoria University of Wellington \\ Kim-Shyan Fam \\ Victoria University of Wellington \\ Geoff Plimmer \\ Victoria University of Wellington \\ Stephan Gerschewski \\ Hankuk University of Foreign Studies
}

\begin{abstract}
The ranking of academic journals continues to be a contentious issue in the tertiary education environment. Academics dependency on journal ranking for tenure and promotion, based on perceived quality and prestige of journals, ensures debate over what constitutes a 'good' journal publication. This study utilises the vox populi MAG score established in previous research in order to continue the assessment of journal ranking and impact in the field of marketing. The current findings are consistent with the previous 2009 study; the top six journals remain the same, there is little variation within the top 30 journal rankings, although regional differences are apparent. The ranking results from a broad range of academics continue to provide a comprehensive measure of journal impact from the perspective of academics.
\end{abstract}

Keywords: Journal ranking, impact factor, vox populi, marketing, ranking criteria

\section{Introduction}

Journal rankings and academic quality continues to attract attention from social science academics, education management and policy makers (Lee, 2011). Publishing in "A" journals have become synonymous for academic quality, reflecting the research value of academics, and representing institutional excellence. Fortunately (or unfortunately), a number of "quality" journal lists exist (e.g., Scopus, SSCI, UTD, $\mathrm{RAE} / \mathrm{REF}, \mathrm{ABDC}$ ) which have been used to influence academic hiring, tenure, promotion decisions, and individual evaluation (Saunders and Wong, 2011). 
This study is the second in a planned series of triennial longitudinal studies examining the ranking of journals by academics around the world, including the personal and career impact on academics of publishing in ranked journals. The current paper only presents the journal ranking data for discussion. As in the previous study (Fam et al., 2011), the research attempts to understand the effect of journal ranking from the 'contributor' perspective, using the vox populi approach; that any judgment based on the intelligence of the masses will be free of passion and uninfluenced by rhetoric (Galton, 1907). More recently, research on the "wisdom of crowds" has found public opinion to be an effective predictive tool because of the capacity to synthesise large amounts of information and improve their judgement (Hastie and Kameda, 2005; Mannes, 2009; Soll and Larrick, 2009; Surowiecki, 2004). This approach attempts to address the direction suggested by Steward and Lewis (2010) that "...efforts aimed at creating new perspectives on appraising the quality of journals in Marketing should be encouraged".

Educational institutions continue to use publishing metrics to measure their influence, progress and research merit. There are a number of ostensibly objective methods used to rank or rate academic journals; however, there is no one 'correct' ranking methodology which supersedes all others. It is to the benefit of the Marketing discipline that alternative perspectives are considered and validated (Steward and Lewis, 2010).

The study contributes to the ongoing discourse on business research quality assessment and journal ranking by examining marketing academic publication ranking across a representative academic spectrum (e.g., from lecturers to professors), not solely based on leading business schools or the academic elite (Theoharakis and Hirst, 2002; Van Fleet et al., 2000). In addition the study considers the relative impact of a number of journal ranking criteria, the journals in which academics actually publish, and differences between regions. The vox populi approach, considering views from a wide range of academics from around the world provides a more balanced view of journal quality. Finally, the study compares the results against two other generally accepted impact factor based journal ranking lists.

\section{Methodology}

Academics were asked to freely recall and nominate up to ten journals. This unaided "top-of-the-mind" method is used extensively in measuring advertisement effectiveness and brand recall as it accesses schema and long term memory without cues (Bagozzi and Silk, 1983; Finn, 1992; Krugman, 1986; Shapiro and Krishnan, 2001; Stapel, 1998; Till and Baack, 2005). In the current case, this method was used to assess academics awareness of " $\mathrm{A}$ " grade journals.

\section{Sampling}

To implement the vox populi sampling approach, this study developed a sampling frame of academics by scanning marketing, tourism, and international business departmental web sites of universities across the five continents. In total, 8,355 
potential respondents were identified from Shanghai Jiao Tong University Ranking 2010 List, Times Supplement University Ranking 2010 List (excluding academics not listed on the Shanghai Jiao Tong List), ANZMAC Conference Directory of Academics, and a further 300 universities located in South Africa, Asia/South Pacific, Australia, New Zealand, USA, Middle East, South America and Europe that were not present on any of the above lists. Respondents included academics from all levels (lecturers, senior lecturers, assistant professors, associate professors, professors, and chair professors). Two weeks following the initial email invitation, a follow-up email was sent.

\section{Survey Instrument}

The survey instrument consisted of three sections. The first section asked respondents to recall up to ten A-grade journals, and to indicate which of these journals respondents had published in since 2006. In addition the respondents were asked to list any other journals they had published in. The second section addressed career, life-balance, family and health considerations with respect to publishing, while the third section collected demographic information.

\section{Result}

Of the 8,355 potential respondents contacted by email, 825 returned out-of office auto-generated messages, 982 had "undeliverable" e-mails (e.g., invalid e-mail addresses), 87 others declined to participate and 4,641 provided no response to either email. In total 1,820 usable responses were collected giving an overall response rate of $21.8 \%$. Following data cleaning and verification, the final sample size was 1,005 cases $(12.0 \%)$. This number of respondents was a significant $(186 \%)$ increase from the previous study (Fam et al., 2011). The respondents were full-time academics from marketing, tourism or international business.

The file was examined visually for appropriate journal names, standard journal names (from the journal site) were adopted and the data reviewed and journal names changed to reflect the standard names. Formulas were created to sort journals and the different ranking methods were calculated.

The cleaned and verified data was then input into SPSS, where CFA and EFA were completed for each of the constructs.

\section{Survey data Analysis}

Table 1 indicates that the single highest numbers of respondents were mid-career, aged 35 to $44(22 \%)$, while $10 \%$ (101) were in their early career. The majority of the respondents $34.4 \%$ (aged 45 to 64 ) were well established in their academic career. There were 471 males (46.9\%) and 210 females (20.9\%), 324 respondents did not report their gender. 
Table 1: Age demographics

\begin{tabular}{lll}
\hline Age & Frequency & Percent \\
\hline 25 to 34 & 101 & 10.0 \\
\hline 35 to 44 & 221 & 22.0 \\
\hline 45 to 54 & 173 & 17.2 \\
\hline 55 to 64 & 173 & 17.2 \\
\hline 65 to 70 & 35 & 3.5 \\
\hline 71 or over & 16 & 1.6 \\
\hline Missing & 286 & 28.5 \\
\hline & 1005 & 100 \\
\hline
\end{tabular}

The majority of respondents are from the United States of America (31.7\%), followed by the United Kingdom (9.4\%) Australia (7.9\%), Canada (4.3\%) and New Zealand (3.7\%), see Table 2 . This compares favourably with the previous survey, although $285(28.3 \%)$ respondents did not provide their country of residence, with $222(41.3 \%)$ respondents from the United States and Canada, 142 (26.3\%) from UK and Europe, $114(21.2 \%)$ from Australia and New Zealand, and 60 (11.2\%) from Asia and Africa.

Table 2: Respondents by country

\begin{tabular}{lcc|lcc}
\hline Country & Frequency & Percent & Country & Frequency & Percent \\
\hline United States of America & 319 & 31.7 & Greece & 2 & 0.2 \\
\hline United Kingdom & 94 & 9.4 & Israel & 2 & 0.2 \\
\hline Australia & 79 & 7.9 & Japan & 2 & 0.2 \\
\hline Canada & 43 & 4.3 & Portugal & 2 & 0.2 \\
\hline New Zealand & 37 & 3.7 & Saudi Arabia & 2 & 0.2 \\
\hline Hong Kong & 15 & 1.5 & Singapore & 2 & 0.2 \\
\hline France & 14 & 1.4 & Turkey & 2 & 0.2 \\
\hline Netherlands & 14 & 1.4 & Viet Nam & 2 & 0.2 \\
\hline Sweden & 10 & 1.0 & Bangladesh & 1 & 0.1 \\
\hline Austria & 9 & 0.9 & Belgium & 1 & 0.1 \\
\hline China & 9 & 0.9 & Brazil & 1 & 0.1 \\
\hline Malaysia & 9 & 0.9 & Egypt & 1 & 0.1 \\
\hline Norway & 9 & 0.9 & Hungary & 1 & 0.1 \\
\hline South Africa & 7 & 0.7 & Indonesia & 1 & 0.1 \\
\hline Denmark & 5 & 0.5 & Poland & 1 & 0.1 \\
\hline India & 5 & 0.5 & Republic of Korea & 1 & 0.1 \\
\hline Ireland & 4 & 0.4 & Spain & 1 & 0.1 \\
\hline Finland & 3 & 0.3 & Switzerland & 1 & 0.1 \\
\hline Germany & 3 & 0.3 & United Arab Emirates & 1 & 0.1 \\
\hline Thailand & 3 & 0.3 & United Republic & of & 1 \\
\hline
\end{tabular}




\section{Journal Ranking}

The six A* journals included Journal of Marketing with the highest number of unaided recalls, 714 (9.9\%), followed by Journal of Marketing Research with 659 (9.2\%) unaided recalls, Journal of Consumer Research with 598 (8.3\%), Marketing Science with 470 (6.5\%), Journal of Academy of Marketing Science with 389 (5.4\%), and the Journal of Retailing with 282 (3.9\%).

Overall, the academics who responded indicated that they had published 1,444 articles in 501 journals. Of these articles, 688 (47.6\%) were published in the top ten journals with $93(6.4 \%)$ papers published in the Journal of Marketing, 82 (5.7\%) papers in the Journal of Marketing Research, $86(6.0 \%)$ papers in the Journal of Consumer Research, 45 (3.1\%) papers in Marketing Science, 74 (5.1\%) papers in the Journal of Academy of Marketing Science and 37 (2.6\%) papers in the Journal of Retailing. A total of 417 papers were published in the six top-ranked journals, see Table 3.

Table 3: A* Publications by region

\begin{tabular}{lccccccc}
\hline A* Journals & Overall & NA & UK & ANZ & \multicolumn{2}{c}{ Asia } & Europe ROW \\
\hline Journal of Marketing & 93 & 49 & 2 & 2 & 3 & 11 & 1 \\
\hline Journal of Marketing Research & 82 & 40 & 1 & 2 & 3 & 8 & 0 \\
\hline Journal of Consumer Research & 86 & 55 & 0 & 2 & 3 & 4 & 1 \\
\hline Marketing Science & 45 & 21 & 1 & 4 & 2 & 6 & 0 \\
\hline Journal of Academy of Marketing Science & 74 & 44 & 1 & 6 & 7 & 4 & 0 \\
\hline Journal of Retailing & 37 & 20 & 1 & 2 & 2 & 4 & 0 \\
\hline Total & 417 & 229 & 6 & 18 & 20 & 37 & 2 \\
\hline
\end{tabular}

Note: See Appendix A for the list of countries included in each region. ROW $=$ Rest of the World.

Regionally, US academics reported the highest number of publications in the Journal of Marketing (43, Canada with 6), and the highest number of $\mathrm{A}^{*}$ publications overall with 202, (Canada had 27 A* publications).

Table 4 shows that although the top ten rankings are similar, there are some significant regional differences. Outside North America international and European related journals are ranked higher, especially by the UK respondents. The Journal of Service Research is ranked highest by Australia and New Zealand, which may represent an academic focus on service in the area, while the UK respondents rank European Journal of Marketing, Journal of Marketing Management, and Industrial Marketing Management altogether higher than most other regions. Acta Commercii is a an obvious outlier, it is a South African management journal ranked within the top ten by those respondents designated in the rest of the world, due to the small number of respondents (15) overall. 
Table 4: Top ten journals as ranked by regions

\begin{tabular}{lccccccc}
\hline & \multicolumn{5}{c}{ Journal Rank by Region } \\
Journal & NA & ANZ & UK & Eur & Asia & ROW \\
\hline Journal of Marketing & $\mathbf{1}$ & $\mathbf{1}$ & $\mathbf{1}$ & $\mathbf{1}$ & $\mathbf{1}$ & $\mathbf{1}$ \\
\hline Journal of Marketing Research & $\mathbf{2}$ & $\mathbf{2}$ & $\mathbf{2}$ & $\mathbf{2}$ & $\mathbf{1}$ & $\mathbf{2}$ \\
\hline Journal of Consumer Research & $\mathbf{3}$ & $\mathbf{2}$ & $\mathbf{3}$ & $\mathbf{3}$ & $\mathbf{3}$ & $\mathbf{3}$ \\
\hline Marketing Science & $\mathbf{4}$ & $\mathbf{7}$ & $\mathbf{6}$ & $\mathbf{4}$ & $\mathbf{5}$ & $\mathbf{3}$ \\
\hline Journal of Academy of Marketing Science & $\mathbf{5}$ & $\mathbf{4}$ & $\mathbf{4}$ & $\mathbf{6}$ & $\mathbf{4}$ & $\mathbf{5}$ \\
\hline Journal of Retailing & $\mathbf{6}$ & $\mathbf{8}$ & $\mathbf{5}$ & $\mathbf{7}$ & $\mathbf{6}$ & $\mathbf{1 0}$ \\
\hline Journal of Consumer Psychology & $\mathbf{7}$ & 29 & 14 & $\mathbf{9}$ & $\mathbf{8}$ & 14 \\
\hline Journal of Advertising & $\mathbf{8}$ & 11 & 26 & 20 & 22 & 14 \\
\hline Management Science & $\mathbf{8}$ & 31 & 37 & $\mathbf{9}$ & 14 & 14 \\
\hline Journal of Business Research & $\mathbf{1 0}$ & $\mathbf{6}$ & $\mathbf{1 0}$ & 19 & $\mathbf{1 0}$ & $\mathbf{8}$ \\
\hline Academy of Management Journal & 11 & 23 & 12 & $\mathbf{8}$ & $\mathbf{1 0}$ & 14 \\
\hline Journal of International Business Studies & 11 & 16 & $\mathbf{1 0}$ & 11 & $\mathbf{6}$ & 14 \\
\hline International Journal of Research in Marketing & 15 & $\mathbf{9}$ & 12 & $\mathbf{5}$ & $\mathbf{8}$ & $\mathbf{6}$ \\
\hline Journal of Service Research & 17 & $\mathbf{1 0}$ & 26 & 14 & 22 & 14 \\
\hline Industrial Marketing Management & 26 & 13 & $\mathbf{9}$ & 26 & 17 & $\mathbf{8}$ \\
\hline European Journal of Marketing & 31 & $\mathbf{5}$ & $\mathbf{7}$ & 18 & $\mathbf{1 0}$ & $\mathbf{6}$ \\
\hline Journal of Marketing Management & 52 & 11 & $\mathbf{8}$ & 34 & - & 14 \\
\hline Acta Commercii & - & - & - & - & - & $\mathbf{1 0}$ \\
\hline Not the & & &
\end{tabular}

Note: the relative position of journals outside of other region's top ten are shown in small italicised font.

To explore whether the large number of US respondents biased the journal rankings, the data was analysed without the US data $(n=400)$, see Appendix D for details of the top 100 journals. There were no significant differences in the top six rankings without the US data. However, it is evident that the non-US data shows a more international flavour, with European Journal of Marketing and International Journal of Research in Marketing moving to $7^{\text {th }}$ and $8^{\text {th }}$ place and an overall increase in the number of international journals below the top 30, including more eclectic journals. The US and non-US data appear similar through the top 29 rankings; however the US data includes more classically (quantitative and US) focused journals.

\section{Ranking criteria}

In addition to the journal ranking exercise, each respondent was also asked to indicate the relative importance (weighting) of seven factors in ranking journals, see Table 5. In order to ensure relative weighting was considered, each respondent provided a weighting for each of the seven factors which had to total to $100 \%$. 
Table 5: Journal ranking criteria as perceived by respondents

\begin{tabular}{lll}
\hline Criteria & Weight & Rank \\
\hline Impact factor & 24.64 & 1 \\
Perceptive studies & 18.84 & 2 \\
Contribution to knowledge & 18.48 & 3 \\
Contribution to career & 10.87 & 4 \\
Rejection rate & 9.59 & 5 \\
Useful for research students & 8.90 & 6 \\
Esteem factors & 8.68 & 7 \\
\hline
\end{tabular}

The results showed that overall impact factor provided the greatest impact on ranking, with a weighting of 24.6, but was not the only criteria considered important. The use of perceptive studies to rank the journals and contribution to knowledge were also major contributors to journal ranking.

\section{MAG Score}

MAG Scholar is the abbreviation for the Marketing in Asia Group (www.magscholar.com) which initiated and supports the ongoing study. The study designed a formula to capture the relative standing of these journals. Since each journal has its own features and merits, the first unaided recalled journal was allocated more weight than the second, third, fourth, and so on, until the tenth position. The sum of each journal's value was labelled the MAG score, and this score was used to rank the journal relative to the others, see Appendix B for example.

MAG score $\left.=\sum_{j}\left(\left(\mathbf{R}_{i j} / \sum \mathbf{T}_{j}\right)\right) / \operatorname{Rank}_{j}\right)$

Note: $\mathrm{R}_{i j}$ is the number of unaided recalls for the $i^{\text {th }}$ journal $(i=1-632)$ with $j^{\text {th }} \operatorname{rank}(j=1,2$, $3, \ldots, 10)$, and $\mathrm{T}$ is the total number of unaided recalls for all journals with rank $j$. Rank $k_{j}$ represents the rank of the journal.

In addition, a MAG index was computed where a value of "100" was attributed to the number 1 journal. The indices for the remaining journals were calculated based on their respective MAG scores relative to the number 1 journal. Table 6 contains the top 50 MAG journals based on the number of journal recalls; the MAG scores combined with the MAG index was used to guide the rank separations. For comparative purposes, the table also shows the 2009 MAG journal ranking. The complete list of journal rankings can be found at www.magscholar.com . 
Table 6: Top 50 Marketing journals and MAG scores

\begin{tabular}{|c|c|c|c|c|c|c|c|}
\hline \multicolumn{3}{|l|}{ Rank } & \multicolumn{5}{|c|}{2011} \\
\hline 2011 & 2009 & Journal & \begin{tabular}{|l|} 
Total \\
Recalls
\end{tabular} & $\begin{array}{l}\text { MAG } \\
\text { Score }\end{array}$ & $\begin{array}{l}\text { MAG } \\
\text { Index }\end{array}$ & $\Delta$ & Cat \\
\hline 1 & 1 & Journal of Marketing & 714 & 0.536 & 100.00 & 206.43 & $A^{*}$ \\
\hline 2 & 2 & Journal of Marketing Research & 659 & 0.330 & 61.50 & 57.72 & $A^{*}$ \\
\hline 3 & 3 & Journal of Consumer Research & 598 & 0.272 & 50.74 & 111.51 & $A^{*}$ \\
\hline 4 & 4 & Marketing Science & 470 & 0.161 & 29.94 & 51.40 & $A^{*}$ \\
\hline 5 & 5 & Journal of Academy of Marketing Science & 389 & 0.109 & 20.35 & 29.35 & $A^{*}$ \\
\hline 6 & 6 & Journal of Retailing & 282 & 0.080 & 14.88 & 12.91 & $A^{*}$ \\
\hline 7 & 14 & Academy of Management Journal & 139 & 0.067 & 12.47 & 8.00 & A \\
\hline 8 & 7 & Journal of International Business Studies & 137 & 0.059 & 10.98 & 1.61 & A \\
\hline 9 & 16 & Journal of Consumer Psychology & 184 & 0.057 & 10.68 & 6.35 & A \\
\hline 10 & 9 & Journal of Business Research & 166 & 0.051 & 9.50 & 1.32 & A \\
\hline 11 & 11 & Management Science & 148 & 0.050 & 9.25 & 4.93 & A \\
\hline 12 & 23 & Strategic Management Journal & 119 & 0.049 & 9.11 & 4.20 & A \\
\hline 13 & 8 & European Journal of Marketing & 130 & 0.045 & 8.33 & 1.15 & A \\
\hline 14 & 15 & Academy of Management Review & 99 & 0.044 & 8.12 & 3.43 & A \\
\hline 15 & 10 & International Journal of Research in Marketing & 148 & 0.040 & 7.48 & 0.22 & A \\
\hline 16 & 13 & Journal of Advertising & 118 & 0.037 & 6.83 & 9.79 & A \\
\hline 17 & 12 & Annals of Tourism Research & 49 & 0.027 & 5.01 & 0.49 & A \\
\hline 18 & 26 & Administrative Science Quarterly & 67 & 0.026 & 4.92 & 1.34 & A \\
\hline 19 & 27 & Journal of Service Research & 79 & 0.025 & 4.67 & 1.74 & A \\
\hline 20 & 25 & Industrial Marketing Management & 71 & 0.023 & 4.34 & 0.84 & A \\
\hline 21 & 21 & Journal of Advertising Research & 66 & 0.022 & 4.18 & 1.09 & A \\
\hline 22 & 18 & Tourism Management & 41 & 0.021 & 3.98 & 1.76 & A \\
\hline 23 & 33 & Journal of Public Policy and Marketing & 63 & 0.020 & 3.65 & 0.49 & A \\
\hline 24 & 28 & Journal of Marketing Management & 58 & 0.019 & 3.56 & 2.29 & A \\
\hline 25 & 20 & Marketing Letters & 56 & 0.017 & 3.13 & 0.57 & $\mathrm{~B}$ \\
\hline 26 & 30 & Journal of International Marketing & 56 & 0.016 & 3.03 & 0.16 & $\mathrm{~B}$ \\
\hline 27 & 24 & Harvard Business Review & 47 & 0.016 & 3.00 & 0.11 & $\mathrm{~B}$ \\
\hline 28 & 41 & Psychology \& Marketing & 48 & 0.016 & 2.98 & 0.57 & $\mathrm{~B}$ \\
\hline 29 & 29 & Journal of Travel Research & 31 & 0.015 & 2.87 & 0.70 & $\mathrm{~B}$ \\
\hline 30 & 36 & Journal of Product Innovation Management & 40 & 0.015 & 2.74 & 0.13 & B \\
\hline 31 & 40 & Journal of Business Ethics & 39 & 0.015 & 2.72 & 0.58 & $\mathrm{~B}$ \\
\hline 32 & 46 & Organization Science & 46 & 0.014 & 2.61 & 0.53 & $\mathrm{~B}$ \\
\hline 33 & 109 & Entrepreneurship, Theory and Practice & 30 & 0.014 & 2.51 & 0.59 & $\mathrm{~B}$ \\
\hline 34 & 45 & Journal of Personality and Social Psychology & 40 & 0.013 & 2.40 & 0.00 & $\mathrm{~B}$ \\
\hline 35 & 95 & Journal of Business Venturing & 29 & 0.013 & 2.40 & 0.90 & $\mathrm{~B}$ \\
\hline 36 & 128 & Journal of Operations Management & 21 & 0.012 & 2.23 & 0.46 & $\mathrm{~B}$ \\
\hline 37 & 61 & Journal of Business Logistics & 17 & 0.012 & 2.14 & 0.92 & $\mathrm{~B}$ \\
\hline 38 & 84 & Journal of Applied Psychology & 29 & 0.011 & 1.97 & 0.57 & $\mathrm{~B}$ \\
\hline 39 & 60 & Journal of Consumer Behavior & 34 & 0.010 & 1.87 & 0.02 & $\mathrm{~B}$ \\
\hline 40 & 62 & Journal of Personal Selling and Sales Management & 30 & 0.010 & 1.86 & 0.07 & $\mathrm{~B}$ \\
\hline 41 & 101 & Journal of Macromarketing & 28 & 0.010 & 1.85 & 0.32 & $\mathrm{~B}$ \\
\hline 42 & 87 & Journal of Management & 35 & 0.010 & 1.79 & 0.10 & $\mathrm{~B}$ \\
\hline 43 & 88 & Journal of Management Studies & 30 & 0.010 & 1.77 & 0.32 & $\mathrm{~B}$ \\
\hline 44 & 113 & Organization Studies & 22 & 0.009 & 1.71 & 0.18 & B \\
\hline 45 & 77 & American Economic Review & 15 & 0.009 & 1.61 & 0.30 & $\mathrm{~B}$ \\
\hline 46 & 79 & Journal of World Business & 24 & 0.008 & 1.56 & 0.46 & $\mathrm{~B}$ \\
\hline 47 & 22 & Journal of Services Marketing & 26 & 0.008 & 1.47 & 0.05 & $\mathrm{~B}$ \\
\hline 48 & 90 & Journal of Sustainable Tourism & 21 & 0.008 & 1.46 & 0.38 & $\mathrm{~B}$ \\
\hline 49 & 89 & Quantitative Marketing and Economics & 29 & 0.008 & 1.39 & 0.12 & $\mathrm{~B}$ \\
\hline 50 & NR & Research Policy & 19 & 0.007 & 1.37 & 0.60 & $\mathrm{~B}$ \\
\hline
\end{tabular}

Note: $\Delta=$ difference between JM MAG score multiplied by $1000 . \mathrm{NR}=$ not ranked 


\section{Validation}

To further validate the MAG score, correlation analysis of the top 100 MAG score journals was undertaken against the SSCI and Scopus indices (Fam et al., 2011; Steward and Lewis, 2010), see Appendix C. In total 89 of the top 100 MAG Scholar journals are included in the SCOPUS index, while 66 are included in the SSCI database. As shown in Table 7, the correlation between the MAG scholar ranked journals and the Scopus, $r(87)=.40, p<.01$, and SSCI, $r(64)=.34, p<.05$, rankings are positive and significant. This indicates that the MAG Scholar list is broadly similar to both the Scopus and SSCI indices.

Table 7: Correlation Matrix: MAG, Scopus and SSCI ranking

\begin{tabular}{l|l|l|l}
\hline & MAG & Scopus & SSCI \\
\hline MAG & 1 & & \\
\hline Scopus & $.40^{* *}$ & 1 & \\
\hline SSCI & $.34 *$ & $.81 * *$ & 1 \\
\hline
\end{tabular}

**. Correlation is significant at the 0.01 level (2-tailed).

*. Correlation is significant at the 0.05 level (2-tailed).

\section{Conclusion}

In an educational environment that considers performance on the basis of objective measures, publishing in highly ranked journals are an important indicator of perceived quality. The key questions are not; are the rankings valid or without bias?, but "are there other valid measures of journals rankings?" and "do the rankings indicate quality?" (Lee, 2011). This study used the vox populi approach in order to introduce an element of 'crowd sourcing' from which to enhance and augment the spectrum of academically ranked journals in the marketing domain (Mannes, 2009). As Steward and Lewis (2010) suggest, Marketing journals are ultimately appraised by members of the Marketing research community, and investigating a variety of validated ranking measures will only "...strengthen the scientific integrity of the Marketing discipline ..."

The top six journals, regardless of region, are: Journal of Marketing, Journal of Marketing Research, Journal of Consumer Research, Marketing Science, Journal of Academy of Marketing Science, and the Journal of Retailing. These results are similar to other studies identified in the literature (Steward and Lewis, 2010). The contribution from this study is the use of a wide spectrum of academics across multiple countries to gather the ranking data; thus the ranking provides an international perspective by design. In addition, the high correlation results with Scopus and SSCI provides evidence that the MAG rankings are reliable when compared against other ranking indices (Steward and Lewis).

The results also demonstrate that the six top ranked journals remain the most highly ranked even when the US data is removed. This implies a uniform recognition of quality and a consistency of quality perception internationally. More interestingly is the divergence of journal rankings, below the top six. The data set without US data 
indicates an emphasis on international marketing journals, while the data set including US data rank general management journals higher.

Although there are strong correlations between the MAG method, Scopus and SSCI, there are large differences in philosophy and in statistical variance. Both Scopus and SSCI are actuarial counting of citation rates, and are based on the logical inference that the more often a journal's articles are cited, the more prestigious that journal is. In contrast, the vox populi method used here may have captured the broader range of the uses to which published articles are used - such as teaching, consultancy and contributions to public issues. A case could be made that a focus on research citations too narrowly represents the usefulness of research. A sole focus on high citation rates risks becoming a self-fulfilling prophecy, where publication in top journals is pursued as an outcome in itself rather than as a marker for practical usefulness or genuine contribution to knowledge. As universities are often subject to publish or perish cultures, and are also sometimes accused of failing to do research that is relevant, a broader means of valuing journals might help nudge university life in positive directions.

The current study showed that impact factors are critical, but account for less than $25 \%$ of a journal's perceived ranking. The other six factors vary widely in the extent to which they are valued, and probably still only account for some of the factors (such as its topics) that make a journal useful or not. The diversity of ways that a journal can be useful, and the diversity of academics, suggest that a MAG scholar approach fits Surowiecki's (2004) four important elements for outlining a wise crowd: (1) diversity of opinion, (2) independence, (identified though the range of tertiary institutions and anonymous design) (3) decentralization, and (4) aggregation.

The publication results support the findings of Saunders and Wong (2011), that UK academics (and to a lesser extent UK influenced academics such as found in Australia and New Zealand) are falling behind in $A^{*}$ journal publications compared to the USA, Asia and Europe. As a percentage of respondents UK academics have a $6.4 \%$ publication rate in $A^{*}$ journals, while Australia and New Zealand have a15.5\% publication rate, Asia has a $40.0 \%$ rate and Europe has a $45.1 \%$ publication rate. Given that the top six journals remain relatively stable across regions and over time this should be a concern to UK, Australian and New Zealand researchers and institutions.

Future research should investigate regional differences more fully, including examining the influence of career duration, age and family-life balance. The determination of journal quality, outside of citation and impact continues to come under scrutiny (Lee, 2011), it is therefore important that additional research explore quality criteria from both a wider academic perspective, and a business impact perspective.

\section{Limitations}

The sample consisted of 1,005 self-selected respondents, which may not be representative of all academics, however the sample has increased significantly from the 2009 study, where 538 academics responded. Surveys in which respondents are 
self-selected will contain an element of bias, especially when the data collected have potential personal and career impact; the results from this survey are no different. However, utilising the vox populi approach and continuing to conduct the survey every three years should build a substantial longitudinal data set.

One concern commonly voiced is that importance of emerging journals and attempting to rank them (Fam et al., 2011). A second concern is finding an acceptable method to capture the dynamic nature of journal rankings, as marketing priorities and activities move forward (Steward and Lewis, 2010).

\section{Acknowledgement:}

The authors would like to thank the National Natural Science Foundation of China (70902011) and Victoria University of Wellington FCA Small Grant (114945) for financial support.

\section{References}

Bagozzi, R. P. \& Silk, A. J. (1983), "Recall, recognition, and the measurement of memory for print advertisement". Marketing Science, vol. 2, no. 2, pp. 95.

Fam, K.-S., Shukla, P., Sinha, A., Parackel, M. \& Chai, J. C. Y. (2011), "Rankings in the Eyes of the Beholder: A Vox Populi Approach to Academic Journal Ranking". Asian Journal of Business Research, vol. 1, no. 1, pp. 1-17.

Finn, A. (1992), "Recall, Recognition and the Measurement of Memory for Print Advertisements: A Reassessment". Marketing Science, vol. 11, no. 1, pp. 95-95.

Galton, F. (1907), "Vox populi". Nature, vol. 75, no. 450-451.

Hastie, R. \& Kameda, T. (2005), "The Robust Beauty of Majority Rules in Group Decisions". Psychological Review, vol. 112, no. 2, pp. 494-508.

Krugman, H. E. (1986), "Low Recall and High Recognition of Advertising". Journal of Advertising Research, vol. 26, no. 1, pp. 79-79.

Lee, N. (2011), "Reflections on assessing academic quality in marketing, and the UK REF". European Journal of Marketing, vol. 45, no. 4, pp. 477-483.

Mannes, A. E. (2009), "Are We Wise About the Wisdom of Crowds? The Use of Group Judgments in Belief Revision". Management Science, vol. 55, no. 8, pp. 1267-1279.

Saunders, J. \& Wong, V. (2011), "Manoeuvring towards research decline". European Journal of Marketing, vol. 45, no. 4, pp. 484-512.

Shapiro, S. \& Krishnan, H. S. (2001), "Memory-based measures for assessing advertising effects: A comparison of explicit and implicit memory effects". Journal of Advertising, vol. 30, no. 3, pp. 1-13. 
Soll, J. B. \& Larrick, R. P. (2009), "Strategies for revising judgment: How (and how well) people use others' opinions". Journal of Experimental Psychology: Learning, Memory, and Cognition, vol. 35, no. 3, pp. 780-805.

Stapel, J. (1998), "Recall and Recognition: A Very Close Relationship". Journal of Advertising Research, vol. 38, no. 4, pp. 41-45.

Steward, M. D. \& Lewis, B. R. (2010), "A Comprehensive Analysis of Marketing Journal Rankings". Journal of Marketing Education, vol. 32, no. 1, pp. 75-92.

Surowiecki, J. (2004), The Wisdom of Crowds: Why the many are smarter than the few and how collective wisdom shapes business, economies, societies, and nations, Doubleday, New York, NY.

Theoharakis, V. \& Hirst, A. (2002), "Perceptual differences of marketing journals: A worldwide perspective". Marketing Letters, vol. 13, no. 4, pp. 389-402.

Till, B. D. \& Baack, D. W. (2005), "Recall and persuasion". Journal of Advertising, vol. 34, no. 3, pp. 47-57.

Van Fleet, D. D., McWilliams, A. \& Siegel, D. S. (2000), "A Theoretical and Empirical Analysis of Journal Rankings: The Case of Formal Lists". Journal of Management, vol. 26, no. 5, pp. 839-861. 


\section{Appendix A: List of countries included in each region}

North America (NA, 362) includes USA (319) and Canada (43).

UK (94).

ANZ (116) includes Australia (79) and New Zealand (37).

Asia (50) includes Bangladesh (1), China (9), Hong Kong (15), India (5), Indonesia (1), Japan (2), Malaysia (9), Republic of Korea (1), Singapore (2), Thailand (3), and Vietnam (2).

Europe (82) includes Austria (9), Belgium (1), Denmark (5), Finland (3), France (14), Germany (3), Greece (2), Hungary (1), Ireland (4), Netherlands (14), Norway (9), Poland (1), Portugal (2), Spain (1), Sweden (10), Switzerland (1), and Turkey (2).

Rest of the world (ROW, 15) includes Brazil (1), Egypt (1), Israel (2), Saudi Arabia (2), South Africa (7), United Republic of Tanzania (1), and the United Arab Emirates (1).

\section{Appendix B: Example of the MAG score calculation}

Journal MAG score $\left.=\sum_{j}\left(\left(\mathbf{R}_{i j} / \sum \mathbf{T}_{j}\right)\right) / \operatorname{Rank}_{j}\right)$

Note: $=\mathrm{R}_{i j}$ is the number of unaided recalls for the $i^{\text {th }}$ journal $(i=1-632)$ with $j^{\text {th }} \operatorname{rank}(j=1,2$, $3, \ldots, 10)$, and $\mathrm{T}$ is the total number of unaided recalls for all journals with rank $j$. Rank ${ }_{j}$ represents the rank of the journal.

Example: MAG score for Journal of Marketing

$(426 / 993 / 1)+(114 / 989 / 2)+(75 / 983 / 3)+\ldots(1 / 236 / 10)=0.536$ 
Appendix C: MAG scholar journal ranking compared to Scopus and SSCI rankings

\begin{tabular}{|c|c|c|c|c|c|c|c|}
\hline \multicolumn{2}{|c|}{$\begin{array}{l}\text { MAG } \\
\text { Rk Cat }\end{array}$} & Journal & $\begin{array}{l}\text { Scopus } \\
\text { IF } \\
\end{array}$ & $\begin{array}{l}\text { Scopus } \\
\text { Rank } \\
\end{array}$ & $\begin{array}{l}\text { SSCI } \\
\text { IF } \\
\end{array}$ & $\begin{array}{l}\text { SSCI } \\
\text { Rank } \\
\end{array}$ & $\begin{array}{l}\text { MAG } \\
\text { Score } \\
\end{array}$ \\
\hline 1 & $\mathrm{~A}^{*}$ & Journal of Marketing & 4.71 & 13 & 3.78 & 12 & 0.536 \\
\hline 2 & $\mathrm{~A}^{*}$ & Journal of Marketing Research & 3.60 & 15 & 3.1 & 17 & 0.330 \\
\hline 3 & $\mathrm{~A}^{*}$ & Journal of Consumer Research & 2.68 & 7 & 3.02 & 18 & 0.272 \\
\hline 4 & $\mathrm{~A}^{*}$ & Marketing Science & 2.03 & 61 & 2.19 & 35 & 0.161 \\
\hline 5 & $\mathrm{~A}^{*}$ & Journal of Academy of Marketing Science & 2.48 & 74 & 1.58 & 61 & 0.109 \\
\hline 6 & $\mathrm{~A}^{*}$ & Journal of Retailing & 5.06 & 45 & 4.57 & 4 & 0.080 \\
\hline 7 & A & Academy of Management Journal & 6.02 & 11 & 6.48 & 2 & 0.067 \\
\hline 8 & A & Journal of International Business Studies & 3.91 & 48 & 3.77 & 13 & 0.059 \\
\hline 9 & A & Journal of Consumer Psychology & 4.06 & Z & 5.35 & 3 & 0.057 \\
\hline 10 & A & Journal of Business Research & 1.51 & 128 & 1.29 & 74 & 0.051 \\
\hline 11 & A & Management Science & 2.52 & 20 & 2.23 & 33 & 0.050 \\
\hline 12 & A & Strategic Management Journal & 4.20 & 30 & 4.46 & 6 & 0.049 \\
\hline 13 & A & European Journal of Marketing & 1.29 & 180 & 0.76 & 115 & 0.045 \\
\hline 14 & A & Academy of Management Review & 7.90 & 4 & 7.87 & 1 & 0.044 \\
\hline 15 & A & International Journal of Research in Marketing & 2.21 & 56 & 1.87 & 48 & 0.040 \\
\hline 16 & A & Journal of Advertising & 1.36 & 121 & 1.17 & 83 & 0.037 \\
\hline 17 & A & Annals of Tourism Research & 1.40 & 134 & 1.17 & $\mathrm{Z}$ & 0.027 \\
\hline 18 & A & Journal of Service Research & 2.92 & 57 & 1.67 & 53 & 0.026 \\
\hline 19 & A & Administrative Science Quarterly & 3.51 & 2 & 3.84 & 11 & 0.025 \\
\hline 20 & A & Industrial Marketing Management & 1.88 & 136 & 1.33 & 73 & 0.023 \\
\hline 21 & A & Journal of Advertising Research & 0.70 & 221 & 0.8 & 111 & 0.022 \\
\hline 22 & A & Tourism Management & 2.53 & 90 & 1.88 & 46 & 0.021 \\
\hline 23 & A & Journal of Public Policy and Marketing & 1.85 & 47 & N/A & $\mathrm{X}$ & 0.020 \\
\hline 24 & A & Journal of Marketing Management & N/A & $\mathrm{X}$ & N/A & $\mathrm{X}$ & 0.019 \\
\hline 25 & B & Marketing Letters & 0.91 & 95 & 0.56 & 130 & 0.017 \\
\hline 26 & B & Journal of International Marketing & 2.18 & 190 & 1.59 & 59 & 0.016 \\
\hline 27 & B & Harvard Business Review & 1.70 & 33 & 1.66 & 55 & 0.016 \\
\hline 28 & B & Psychology \& Marketing & N/A & $\mathrm{X}$ & 1.34 & 72 & 0.016 \\
\hline 29 & B & Journal of Travel Research & 1.73 & $\mathrm{Z}$ & N/A & $\mathrm{X}$ & 0.015 \\
\hline 30 & B & Journal of Product Innovation Management & 2.09 & 73 & 1.52 & 63 & 0.015 \\
\hline 31 & B & Journal of Business Ethics & 1.18 & 245 & 1.09 & 89 & 0.015 \\
\hline 32 & B & Organization Science & 3.32 & 46 & 3.13 & 15 & 0.014 \\
\hline 33 & B & Entrepreneurship, Theory and Practice & N/A & $\mathrm{X}$ & N/A & $\mathrm{X}$ & 0.014 \\
\hline 34 & B & Journal of Personality and Social Psychology & 4.82 & Z & 4.73 & Z & 0.013 \\
\hline 35 & B & Journal of Business Venturing & 2.92 & 52 & 2.26 & 31 & 0.013 \\
\hline 36 & B & Journal of Operations Management & 4.60 & 24 & 3.24 & 14 & 0.012 \\
\hline 37 & B & Journal of Business Logistics & N/A & $\mathrm{X}$ & N/A & $\mathrm{X}$ & 0.012 \\
\hline 38 & B & Journal of Applied Psychology & 4.33 & Z & 3.84 & Z & 0.011 \\
\hline 39 & B & Journal of Consumer Behavior & N/A & $\mathrm{X}$ & N/A & $\mathrm{X}$ & 0.010 \\
\hline 40 & B & Journal of Personal Selling and Sales Management & 1.54 & 182 & N/A & $\mathrm{X}$ & 0.010 \\
\hline 41 & B & Journal of Macromarketing & 1.20 & 214 & N/A & $\mathrm{X}$ & 0.010 \\
\hline 42 & B & Journal of Management & 4.87 & 22 & 4.43 & 7 & 0.010 \\
\hline 43 & B & Journal of Management Studies & 3.13 & 39 & 2.81 & 19 & 0.010 \\
\hline 44 & B & Organization Studies & 2.47 & 70 & 2.12 & 38 & 0.009 \\
\hline 45 & B & American Economic Review & 2.65 & $\mathrm{Z}$ & 2.53 & Z & 0.009 \\
\hline 46 & B & Journal of World Business & 2.79 & 137 & 2.63 & 20 & 0.008 \\
\hline 47 & B & Journal of Services Marketing & 1.02 & 218 & N/A & $\mathrm{X}$ & 0.008 \\
\hline 48 & B & Journal of Sustainable Tourism & 1.08 & 162 & N/A & $\mathrm{X}$ & 0.008 \\
\hline 49 & B & Quantitative Marketing and Economics & 1.19 & 119 & N/A & $\mathrm{X}$ & 0.008 \\
\hline 50 & B & Research Policy & N/A & $\mathrm{X}$ & 2.26 & 30 & 0.007 \\
\hline 51 & B & Management International Review & 1.83 & 224 & N/A & $\mathrm{X}$ & 0.007 \\
\hline
\end{tabular}




\begin{tabular}{|c|c|c|c|c|c|c|c|}
\hline 52 & B & Psychological Science & 4.87 & Z & 5.09 & $\mathrm{Z}$ & 0.006 \\
\hline 53 & B & Consumption, Markets \& Culture & N/A & $\mathrm{X}$ & N/A & $\mathrm{X}$ & 0.006 \\
\hline 54 & B & MIS Quarterly & 5.65 & 12 & 4.49 & 5 & 0.006 \\
\hline 55 & B & $\begin{array}{l}\text { Organizational Behavior and Human Decisic } \\
\text { Processes }\end{array}$ & on 2.22 & 6 & 2.55 & 23 & 0.006 \\
\hline 56 & B & Journal of Interactive Marketing & 3.91 & 69 & 2.6 & 21 & 0.006 \\
\hline 57 & B & International Marketing Review & 1.46 & 194 & 1.16 & 84 & 0.006 \\
\hline 58 & B & Journal of Finance & 4.07 & 5 & 3.76 & Z & 0.006 \\
\hline 59 & B & International Journal of Market Research & 1.27 & 166 & 0.99 & 96 & 0.006 \\
\hline 60 & B & Marketing Theory & 0.00 & 672 & N/A & $\mathrm{X}$ & 0.006 \\
\hline 61 & B & British Journal of Management & 1.53 & 110 & 1.45 & 66 & 0.005 \\
\hline 62 & B & Journal of Supply Chain Management & 2.35 & 113 & N/A & $\mathrm{X}$ & 0.005 \\
\hline 63 & B & Environment and Planning & 2.04 & $\mathrm{Z}$ & N/A & $\mathrm{X}$ & 0.005 \\
\hline 64 & B & International Business Review & 1.48 & 230 & 1.06 & 92 & 0.005 \\
\hline 65 & B & Journal of Marketing Theory and Practice & 1.31 & 248 & N/A & $\mathrm{X}$ & 0.004 \\
\hline 66 & B & Transportation Research & 2.28 & 79 & N/A & $\mathrm{X}$ & 0.004 \\
\hline 67 & B & Journal of Business and Industrial Marketing & 1.03 & 309 & N/A & $\mathrm{X}$ & 0.004 \\
\hline 68 & B & Decision Sciences & 2.81 & 54 & 2.38 & 26 & 0.004 \\
\hline 69 & B & Journal of Travel and Tourism Marketing & 0.64 & 393 & N/A & $\mathrm{X}$ & 0.004 \\
\hline 70 & B & Sloan Management Review & 1.24 & 122 & N/A & $\mathrm{X}$ & 0.004 \\
\hline 71 & B & Journal of Consumer Affairs & 2.06 & 72 & 2.18 & 36 & 0.004 \\
\hline 72 & B & $\begin{array}{l}\text { International Journal of Physical Distribution } \\
\text { Logistics Management }\end{array}$ & ${ }^{\&} \mathrm{~N} / \mathrm{A}$ & $\mathrm{X}$ & $\mathrm{N} / \mathrm{A}$ & $\mathrm{X}$ & 0.004 \\
\hline 73 & B & Organization & 1.47 & 160 & 1.35 & 70 & 0.003 \\
\hline 74 & B & Tourism Analysis & N/A & $\mathrm{X}$ & N/A & $\mathrm{X}$ & 0.003 \\
\hline 75 & B & Journal of International Management & 2.08 & 172 & 1.85 & 49 & 0.003 \\
\hline 76 & B & Journal of Small Business Management & 1.38 & 215 & 1.09 & 89 & 0.003 \\
\hline 77 & B & Human Resource Management Journal & 1.35 & 124 & N/A & $\mathrm{X}$ & 0.003 \\
\hline 78 & B & Operations Research & 1.70 & $\mathrm{Z}$ & 1.58 & 62 & 0.003 \\
\hline 79 & B & Information Systems Research & 2.21 & Z & 1.79 & 50 & 0.003 \\
\hline 80 & B & Journal of Marketing Education & 0.72 & 238 & N/A & $\mathrm{X}$ & 0.003 \\
\hline 81 & B & Public Opinion Quarterly & 1.48 & Z & N/A & $\mathrm{X}$ & 0.003 \\
\hline 82 & B & California Management Review & 2.60 & 71 & 1.98 & 44 & 0.003 \\
\hline 83 & B & Journal of Political Economy & 4.00 & Z & 3.84 & Z & 0.003 \\
\hline 84 & B & $\begin{array}{l}\text { International Review of Retail Distribution ar } \\
\text { Consumer Research }\end{array}$ & ${ }^{n d} \mathrm{~N} / \mathrm{A}$ & $\mathrm{X}$ & N/A & $\mathrm{X}$ & 0.003 \\
\hline 85 & B & Industrial and Corporate Change & 1.92 & $\mathrm{Z}$ & 1.51 & 64 & 0.003 \\
\hline 86 & B & Journal of Experimental Social Psychology & 2.24 & Z & 2.24 & Z & 0.003 \\
\hline 87 & B & Quarterly Journal of Economics & 5.78 & Z & 5.65 & Z & 0.003 \\
\hline 88 & B & Current Issues in Tourism & 0.70 & 340 & N/A & $\mathrm{X}$ & 0.003 \\
\hline 89 & B & Business History Review & 0.36 & 516 & 0.35 & 144 & 0.003 \\
\hline 90 & B & Science & 24.19 & Z & N/A & $\mathrm{X}$ & 0.002 \\
\hline 91 & B & International Journal of Advertising & 1.40 & 159 & 1.09 & 88 & 0.002 \\
\hline 92 & B & Journal of Consumer Culture & 1.46 & $\mathrm{Z}$ & N/A & $\mathrm{X}$ & 0.002 \\
\hline 93 & B & IEEE Transactions on Engineering Management & 1.90 & 91 & 1.25 & 75 & 0.002 \\
\hline 94 & B & American Journal of Sociology & 3.49 & $\mathrm{Z}$ & 3.48 & $\mathrm{Z}$ & 0.002 \\
\hline 95 & B & Small Business Economics & 1.44 & $\mathrm{Z}$ & 1.38 & 69 & 0.002 \\
\hline 96 & B & Journal of Experimental Psychology & 4.67 & $\mathrm{Z}$ & N/A & $\mathrm{X}$ & 0.002 \\
\hline 97 & B & Accounting, Organizations and Society & 2.58 & 105 & N/A & $\mathrm{X}$ & 0.002 \\
\hline 98 & B & Journal of Financial Economics & 4.43 & 10 & 4.02 & Z & 0.002 \\
\hline 99 & B & European Journal of Operational Research & 2.51 & Z & N/A & $\mathrm{X}$ & 0.002 \\
\hline 100 & B & Human Relations & 1.84 & 84 & 1.64 & 56 & 0.002 \\
\hline
\end{tabular}

Notes: SSCI: Business, Management; Scopus: Business, Management and Accounting.

$Z$ : Not in Business, Management or Business, Management and Accounting category

$\mathrm{X}$ : Not in SSCI or Scopus database 


\section{Appendix D: MAG scholar journal ranking comparing with and without US data}

Journal with US data

\begin{tabular}{lll}
\hline 1 & Journal of Marketing & Total \\
2 & Journal of Marketing Research & 659 \\
3 & Journal of Consumer Research & 598 \\
4 & Marketing Science & 470 \\
5 & Journal of Academy of Marketing Science & 389 \\
6 & Journal of Retailing & 282 \\
\hline 7 & Journal of Consumer Psychology & 184
\end{tabular}

8 Journal of Business Research 166

9 Management Science

148

11

12

13

\section{4}$$
15
$$$$
16
$$

International Journal of Research in Marketing $\begin{array}{ll}\text { Academy of Management Journal } & 139\end{array}$

Journal of International Business Studies

137

European Journal of Marketing 130

4 Strategic Management Journal 119

5 Journal of Advertising 118

6 Academy of Management Review 99

17 Journal of Service Research 79

8 Industrial Marketing Management 71

9 Administrative Science Quarterly 67

0 Journal of Advertising Research 66

1 Journal of Public Policy and Marketing 63

2 Journal of Marketing Management 58

3 Journal of International Marketing 56

4 Marketing Letters 56

25 Annals of Tourism Research 49

6 Psychology \& Marketing 48

7 Harvard Business Review 47

2 Organization Science 46

29 Tourism Management 41

30 Journal of Product Innovation Management 40

1 Journal of Personality and Social Psychology 40

32 Journal of Business Ethics 39

33 Journal of Management 35

34 Journal of Consumer Behavior 34

35 Journal of Travel Research 31

36 Entrepreneurship, Theory and Practice 30

37 Journal of Personal Selling and Sales 30 Management

\section{Journal without US data}

Total

Journal of Marketing 265

Journal of Marketing Research 232

Journal of Consumer Research 208

Marketing Science 160

Journal of Academy of Marketing Science 155

Journal of Retailing

115

European Journal of Marketing 91

International Journal of Research in 91 Marketing

Journal of Business Research 79

Journal of International Business Studies 64

Academy of Management Journal 62

Journal of Consumer Psychology 52

Industrial Marketing Management 45

Academy of Management Review $\quad 43$

Journal of Marketing Management $\quad 42$

Journal of Service Research $\quad 41$

Management Science $\quad 37$

Journal of Advertising $\quad 36$

Annals of Tourism Research $\quad 35$

Strategic Management Journal 33

Administrative Science Quarterly $\quad 32$

Journal of International Marketing $\quad 27$

Tourism Management 26

Organization Science 25

Marketing Letters 24

Journal of Product Innovation Management 23

Psychology \& Marketing 22

Journal of Advertising Research 21

Journal of Business Ethics $\quad 18$

Journal of Management Studies $\quad 17$

Journal of Travel Research $\quad 17$

Journal of Consumer Behavior $\quad 15$

Journal of Sustainable Tourism $\quad 15$

Organization Studies $\quad 15$

Harvard Business Review 14

International Marketing Review $\quad 13$

Journal of Business Venturing 13

Journal of Management 13

Journal of World Business 13

Entrepreneurship, Theory and Practice 12

Journal of Public Policy and Marketing 12 


\begin{tabular}{|c|c|c|}
\hline 42 & Journal of Macromarketing & 28 \\
\hline 43 & Journal of Services Marketing & 26 \\
\hline 44 & Journal of World Business & 24 \\
\hline 45 & Organization Studies & 22 \\
\hline 46 & $\begin{array}{l}\text { Organizational Behavior and Human Decision } \\
\text { Processes }\end{array}$ & 22 \\
\hline 47 & Journal of Operations Management & 21 \\
\hline 48 & Journal of Sustainable Tourism & 21 \\
\hline 49 & Psychological Science & 21 \\
\hline 50 & International Marketing Review & 21 \\
\hline 51 & Research Policy & 19 \\
\hline 52 & Management International Review & 19 \\
\hline 53 & Journal of Interactive Marketing & 19 \\
\hline 54 & Journal of Business Logistics & 17 \\
\hline 55 & Marketing Theory & 17 \\
\hline 56 & British Journal of Management & 17 \\
\hline 57 & Consumption, Markets \& Culture & 16 \\
\hline 58 & International Business Review & 16 \\
\hline 59 & American Economic Review & 15 \\
\hline 60 & International Journal of Market Research & 15 \\
\hline 61 & Environment and Planning & 15 \\
\hline 62 & Sloan Management Review & 15 \\
\hline 63 & MIS Quarterly & 13 \\
\hline 64 & Decision Sciences & 13 \\
\hline 65 & Journal of Supply Chain Management & 12 \\
\hline 66 & Journal of Marketing Theory and Practice & 12 \\
\hline 67 & Journal of Business and Industrial Marketing & 12 \\
\hline 68 & Journal of Travel and Tourism Marketing & 12 \\
\hline 69 & Tourism Analysis & 12 \\
\hline 70 & Journal of International Management & 12 \\
\hline 71 & Journal of Small Business Management & 10 \\
\hline 72 & Journal of Marketing Education & 10 \\
\hline 73 & California Management Review & 9 \\
\hline 74 & Journal of Political Economy & 9 \\
\hline 75 & Industrial and Corporate Change & 9 \\
\hline 76 & Journal of Experimental Social Psychology & 9 \\
\hline 77 & Journal of Finance & 8 \\
\hline 78 & $\begin{array}{l}\text { International Journal of Physical Distribution \& } \\
\text { Logistics Management }\end{array}$ & 8 \\
\hline 79 & Operations Research & 8 \\
\hline 80 & Current Issues in Tourism & 8 \\
\hline 81 & Quarterly Journal of Economics & 8 \\
\hline
\end{tabular}

\begin{tabular}{ll} 
British Journal of Management & 11 \\
Environment and Planning & 11 \\
Journal of Macromarketing & 11 \\
Marketing Theory & 11 \\
Consumption, Markets \& Culture & 10 \\
Journal of Applied Psychology & 10 \\
International Business Review & 9 \\
Journal of Interactive Marketing & 9 \\
International Journal of Market Research & 8 \\
\hline Journal of Consumer Marketing & 8 \\
Advances in Consumer Research & 5 \\
Current Issues in Tourism & 5 \\
Industrial and Corporate Change & 5
\end{tabular}

Industrial and Corporate Change 5

Journal of Advertising and Marketing 5 Communications

Journal of Business and Industrial 5 Marketing

American Economic Review 4

ASQ

4

California Management Review 4

Human Relations 4

International Journal of Hospitality 4 Management

Accounting, Organizations and Society 3

Australian Journal of Management 3

Economic Journal 3

European Journal of Operational Research 3

Information Systems Research 3

International Journal of Advertising 3

International Journal of Human Resource 3 Management

International Journal of Tourism Research 3 International Review of Retail Distribution 3 and Consumer Research

International Small Business Journal 3

Journal of Consumer Culture 3

Academy of Marketing Science Quarterly 2

Acta Commercii 2

Asia Pacific Journal of Marketing 2

Asia Pacific Journal of Marketing and 2 Logistics

Asia Pacific Journal of Tourism Research 2

Asian Journal of Business Research 2

Asian Survey 2

Business Ethics Quarterly 2

Business Horizons 2 


\begin{tabular}{|c|c|c|c|}
\hline 82 & Journal of Consumer Culture & 8 & Decision Sciences \\
\hline 83 & Small Business Economics & 8 & Department of Management Studies \\
\hline 84 & Science & 8 & $\begin{array}{l}\text { Entrepreneurship } \quad \text { and } \quad \text { Regional } \\
\text { Development }\end{array}$ \\
\hline 85 & $\begin{array}{llll}\text { International Journal of Hospitality } \\
\text { Management }\end{array}$ & 8 & Environmental Politics \\
\hline 86 & Journal of Experimental Psychology & 8 & European Economic Review \\
\hline 87 & Human Relations & 8 & European Management Journal \\
\hline 88 & Journal of Organizational Behavior & 8 & Human Resource Management Journal \\
\hline 89 & Journal of Consumer Affairs & 7 & International Journal of Bank Marketing \\
\hline 90 & Human Resource Management Journal & 7 & $\begin{array}{l}\text { International Journal of Contemporary } \\
\text { Hospitality Management }\end{array}$ \\
\hline 91 & Information Systems Research & 7 & $\begin{array}{l}\text { International Journal of Cross Cultural } \\
\text { Management }\end{array}$ \\
\hline 92 & International Journal of Advertising & 7 & $\begin{array}{l}\text { International Journal of Retail \& } \\
\text { Distribution Management }\end{array}$ \\
\hline 93 & International Journal of Logistics Management & 7 & Journal of Brand Management \\
\hline 94 & Tourism Geographies & 7 & Journal of Business \\
\hline 95 & Transportation Research & 6 & $\begin{array}{l}\text { Journal of Business Accounting and } \\
\text { Finance }\end{array}$ \\
\hline 96 & Journal of Marketing Communications & 6 & Journal of Business Logistics \\
\hline 97 & Accounting, Organizations and Society & 6 & Journal of Business to Business Marketing \\
\hline 98 & Journal of Consumer Marketing & 6 & Journal of Common Market Studies \\
\hline 99 & Journal of Strategic Marketing & 6 & Journal of Contemporary Management \\
\hline 100 & $\begin{array}{l}\text { International Journal of Human Resource } \\
\text { Management }\end{array}$ & 6 & Journal of Economic Geography \\
\hline
\end{tabular}

Note: The highlighted listings indicate journals either ranked outside the top 50, or not ranked within the 100 journal listed, (e.g., Journal of Personality and Social Psychology is ranked \#31 with US data included, but is not ranked in the top 100 when US data is not included). 